\title{
PENGEMBANGAN SISTEM OTOMASI PENGOLAHAN KOLEKSI KARYA ILMIAH MAHASISWA BERBASIS WEB UNTUK MENINGKATKAN KUALITAS LAYANAN PERPUSTAKAAN (Studi Kasus : Universitas Pendidikan Ganesha)
}

\author{
I Made Pendra Mahardika ${ }^{1}$, Ni Ketut Rai Yuli², Ni Kadek Etik Suparmini ${ }^{3}$ \\ Unit Perpustakaan UNDIKSHA \\ Singaraja, Indonesia
}
Email : pendramahardika77@gmail.com¹, niketutraiyuli@gmail.com², etikmini@yahoo.com ${ }^{3}$

\begin{abstract}
Abstrak
Tujuan penelitian ini untuk mengembangkan sistem otomasi pengolahan koleksi karya ilmiah mahasiswa berbasis web dalam rangka meningkatkan kualitas layanan karya ilmiah mahasiswa di perpustakaan UNDIKSHA. Metode penelitian yang digunakan adalah metode penelitian dan pengembangan (research and development) dengan paradigma prototyping karena pengembangan perangkat lunak ini dapat dikerjakan secara terpadu antara pustakawan dan pakar teknologi informasi. Hasil rancang bangun kemudian diimplementasikan menjadi perangkat lunak pengolahan koleksi karya ilmiah mahasiswa berbasis web, kemudian program tersebut diuji coba terbatas dengan uji kelayakan oleh pakar teknologi informasi dan uji keterpakaian oleh pengguna (petugas perpustakaan dan mahasiswa undiksha). Hasil ujicoba menunjukkan bahwa:(1) Pengembangan sistem otomasi pengolahan koleksi karya ilmiah mahasiswa berbasis web sudah sesuai dengan spesifikasi yang telah ditentukan sebagai pengolahan dan penelusuran informasi koleksi karya ilmiah mahasiswa yang dilakukan secara otomatis oleh program dengan mudah, cepat dan akurat; (2) Indikator penilaian dari program ini meliputi: kebenaran, keterluasan, efesiensi, portabilitas, verifikasi, modularitas dan keterbacaan, kinerja, kemudahan pemakaian, keramahan, dan kebergunaan mendapatkan kualifikasi baik, sedangkan ketegaran, keterpakaian ulang dan integritas yang dinilai oleh pakar teknologi informasi dengan kualifikasi cukup memadai yang perlu ditingkatkan lagi; (3) Secara umum dari hasil penilaian, dapat dikatakan program sudah cukup layak digunakan oleh pengguna sebagai pengolahan dan penelusuran informasi koleksi karya ilmiah mahasiswa yang berbasis web.
\end{abstract}

Kata kunci : Sistem otomasi,Software, koleksi karya ilmiah, kualitas layanan

\begin{abstract}
The purpose of this research was to develop automated systems processing of the student's scientific works collection through web-based in order to improve the service quality of the students' scientific work in the UNDIKSHA library. Research and development design was applied in this research through prototyping paradigm for software development. It is due to its integrated manner between
\end{abstract}


librarians and the experts of information technology. The developed-software then implemented into the automation system processing through web-based. Besides, the program was also validated by the experts in Information Technology and test its applicability to users. The trial results shows that:(1) the developed software has fullfiled the specification needed in processing and information retrieval that is done easily, quickly, accurately as well as automatically by the program;(2) The assessment indicators of the program include: truth, wideness, efficiency, portability, verification, modularity and readability, performance, ease of use, friendliness, and the usefulness gain good qualification, while the realibility, reusability and integrity which are assessed by the experts gain sufficient qualifications that needs to be improved; (3) the results of these assessments can be concluded that the program is good, especially to fasicilate the user in order to process and retrieve the informations recording the collection of student's scientific work.

Keywords: automation systems, software, collection of scientific papers, the quality of service

\section{PENDAHULUAN}

Perpustakaan berfungsi sebagai wahana pendidikan, penelitian, pelestarian, informasi dan rekreasi untuk meningkatkan kecerdasan dan keberdayaan bangsa. Untuk mendukung hal itu perpustakaan harus dikelola dengan baik, terutama pengelolaan koleksi. Menurut Prastowo (2011:114) dalam manajemen perpustakaan, persoalan koleksi perpustakaan adalah salah satu unsur penting, karena ini terkait dengan substansi atau hakikat manajemen perpustakaan merupakan pengelolaan koleksi perpustakaan yang dilakukan secara efektif dan efesien. Koleksi perpustakaan diseleksi, diolah, disimpan, dilayankan dan dikembangkan sesuai dengan kepentingan pemustaka dengan memperhatikan teknologi informasi dan komunikasi (pasal 4 UU 43 tahun 2007 tentang perpustakaan).

Perpustakaan

Universitas

Pendidikan Ganesha menyediakan berbagai jenis layanan yang dapat dimanfaatkan oleh pengguna dalam memberikan layanan informasi, salah satunya adalah layanan karya ilmiah mahasiswa. Layanan ini diberikan kepada pengguna untuk dapat memanfaatkan koleksi karya ilmiah mahasiwa seperti tugas akhir dan skripsi secara optimal. Dengan bertambahnya koleksi karya ilmiah setiap tahunnya maka diperlukan pengolahan koleksi yang cepat agar pengguna dapat mendayagunakan koleksi secara optimal. Namun pada kenyataanya, banyak mahasiswa yang menanyakan koleksi baru, akan tetapi belum bisa dimanfaatkan karena belum diolah oleh petugas. Dengan keterlambatan proses pengolahan koleksi karya ilmiah mahasiswa oleh petugas perpustakaan berdampak pada pelayanan yang kurang bermutu atau berkualitas. Selain itu, data pada alat penelusuran informasi (katalog) yang digunakan untuk mengetahui lokasi koleksi tidak akurat sehingga koleksi sulit untukditemukan. Menurut Soeatminah(1992:129) menyatakan mutu suatu perpustakaan diukur dari 
kemampuannya memberikan koleksi yang tepat kepada peminat pada saat koleksi tersebut dikehendaki. Hal ini juga senada diungkapkan oleh William $S$, pustakawan pada perpustakaan Princeton University di Amerika Serikat bahwa suatu perpustakaan dianggap bermutu apabila dapat memberi layanan yang cepat, tepat dan benar kepada pemakainya. Agar dapat memberikan setiap pustaka (skripsi atau tugas akhir) yang terkini atau uptodate yang paling diminati oleh pemakai perpustakaan (mahasiswa) diperlukan pengolahan koleksi yang cepat. Koleksi yang paling diminati oleh pemakai pada layanan karya ilmiah mahasiswa adalah koleksi terbaru artinya skripsi atau tugas akhir yang lulusan terbaru.

Saat ini pengolahan koleksi karya ilmiah mahasiswa di perpustakaan UNDIKSHA dilakukan secara manual tanpa didukung oleh aplikasi program. Hal ini dapat berimplikasi kepada kualitas layanan yang diberikan kepada pengguna terutama pada kecepatan pengolahan koleksi yang berdampak pada kecepatan dan ketepatan layanan seperti yang sudah dipaparkan di atas. Selain itu permasalahaan juga terjadi pada saat pengguna melakukan browsing ataupencarian koleksi di rak, ternyata tidak sesuai dengan apa yang diinginkan seperti yang tercantum pada katalog atau alat penelusuran koleksi. Dengan begitu pelayanan yang diberikan kepada pengguna sudah jelas tidak memuaskan pengguna. Pengolahan koleksi yang tidak akurat mengakibatkan kesalahan data pada saat pembuatan klasifikasi atau nomor panggil koleksi yang digunakan untuk memudahkan pengguna menemukan koleksi di rak dengan cepat dan benar tidak dapat terwujud.

Dengan tahapan atau prosedur kerja yang cukup panjang pada saat pengolahan koleksi karya ilmiah mahasiswa dibutuhkan waktu yang cukup lama juga untuk menyelesaikan pekerjaan agar koleksi siap dimanfaatkan. Disisi lain pengguna membutuhkan layanan yang cepat, tepat dan benar sesuai yang diinginkan. Berdasarkan hal itu diperlukan suatu sistem dalam pengolahan koleksi dengan menggunakan teknologi informasi yang disebut sistem otomasi . Menurut Suprianto (2008:23) tujuan penerapan teknologi informasi adalah untuk otomasi kerja perpustakaan, dengan penerapan teknologi informasi dapat mengefisiensikan dan mempermudah pekerjaan dalam perpustakaan dan memberikan layanan yang lebih baik kepada pengguna perpustakaan. Selain itu dengan sistem otomasi, proses pengolahan data koleksi lebih akurat dan dapat dengan cepat ditelusuri kembali. Dengan bantuan sistem otomasi diharapkan para pustakawan juga dapat menggunakan waktu lebihnya untuk mengurusi

perpustakaan karena beberapa pekerjaan yang bersifat berulang sudah diambil alih oleh komputer yang ada dalam sistem otomasi (Retno, 2009).Penerapan teknologi informasi digunakan untuk memberikan layanan yang lebih efektif dan meningkatkan efesiensi kerja (Corbin,1985 dan Rowley,1980). Menurut Suprianto dkk.(2008:37) manfaat otomasi perpustakaan dengan menerapkan kemajuan teknologi informasi akan memberikan manfaat untuk 
mengefesiensikan dan mempermudah pekerjaan dalam perpustakaan dan memberikan layanan yang lebih baik kepada pengguna perpustakaan. Selain dari fenomena yang telah dipaparkan di atas,Penelitian ini merupakan penelitian lanjutan dari penelitian penulis sebelumnya. Penelitian tersebut mengkaji tentang pengembangan program layanan bebas pustaka online. Adapun hasil penelitian tersebut adalah program pengecekan pinjaman buku dan upload file karya ilmiah yang dilakukan oleh mahasiswa secara online untuk pendaftaran wisuda. Program ini bisa diakses di web perpustakaan. Data yang telah masuk pada program ini berupa judul skripsi, nama penulis, jurusan dan file keseluruhan akan diintegrasikan dengan program sistem otomasi pengolahan koleksi karya ilmiah mahasiswa. Data tersebut menjadi bahan dasar yang diperlukan untuk pengembangan sistem otomasi pengolahan koleksi karya ilmiah kemudian diolah sedemikian rupa sesuai dengan kebutuhan pengguna.

Beberapa penelitian lainnya tentang sistem otomasi yang identik dengan penelitian ini telah dilakukan oleh beberapa peneliti dengan kasus yang berbeda-beda. Retno dkk,(2009) telah mengembangkan sistem otomasi penelusuran koleksi umum sebagai upaya peningkatan layanan penelusuran koleksi buku bagi pengguna. Setemen dkk,(2012) telah mengembangkan sistem pengarsipan karya ilmiah mahasiswa dan dosen berbasis web yang mengakomodasi pengelolaan karya akademik mahasiswa dan dosen sebagai rujukan mahasiswa dan dosen melakukan penelitian. Retno Wulan dkk,(2011), telah mengembangkan layanan penelusuran koleksi skripsi dan tugas akhir dengan e-book berbasis sistem elektronic resources. Sistem yang dikembangkan merupakan layanan akses koleksi skripsi dan tugas akhir via internet. Sri rahayu,(2011) telah mengembangkan sistem otomasi dengan optimalisasi fitur pengindeksan winisis untuk ketepatan dan kecepatan layanan penelusuran pustaka kelabu.

Tujuan yang ingin dicapai dalam penelitian ini adalah untuk mengetahui :1) Pengembangan sistem otomasi pengolahan koleksi karya ilmiah berbasis web yang meliputi rancang bangun dan implementasinya. 2) Hasil ujicoba atau evaluasi pengembangan sistem otomasi pengolahan koleksi karya ilmiah mahasiswa berbasis web dari pengguna (pustakawan dan mahasiswa) dan pakar teknologi informasi.

\section{METODE}

Penelitian ini merupakan penelitian pengembangan perangkat lunak. Pada penelitian ini ada dua tahap utama, yaitu: pengembangan dan uji coba (evaluasi) perangkat lunak. Tahapan penelitian ini adalah sebagai berikut.

\section{Metode Penelitian Rancang Bangun}

Penelitian ini merupakan pengembangan perangkat lunak, dengan sasaran akhir yang diharapkan adalah terciptanya sebuah perangkat lunak (software) sesuai dengan spesifikasi yang ditetapkan. Oleh karena itu, metode yang digunakan mengikuti paradigma dalam pengembangan perangkat lunak yaitu paradigma prototyping. Paradigma ini dipilih karena pengembangan perangkat lunak dapat dikerjakan secara terpadu antara 
pustakawan dan pakar teknologi informasi.

Pada

pengembangan

perangkat lunak dengan paradigma prototyping, memungkinkan pengembang untuk membentuk model perangkat lunak (prototipe) yang diharapkan. Prototipe tersebut selanjutnya dievaluasi dan diperbaiki bersama-sama apabila sudah dianggap layak, maka perangkat lunak tersebut langsung diproduksi sedangkan kalau masih ada kekurangan, maka dilakukan perbaikan. Kelebihan paradigma ini adalah terjadi kesesuaian antara permintaan pemakai dengan rancangan yang dibuat oleh pengembang dengan lebih cepat. Urutan langkah pada paradigma prototyping diilustrasikan dalam gambar 1 di bawah ini.

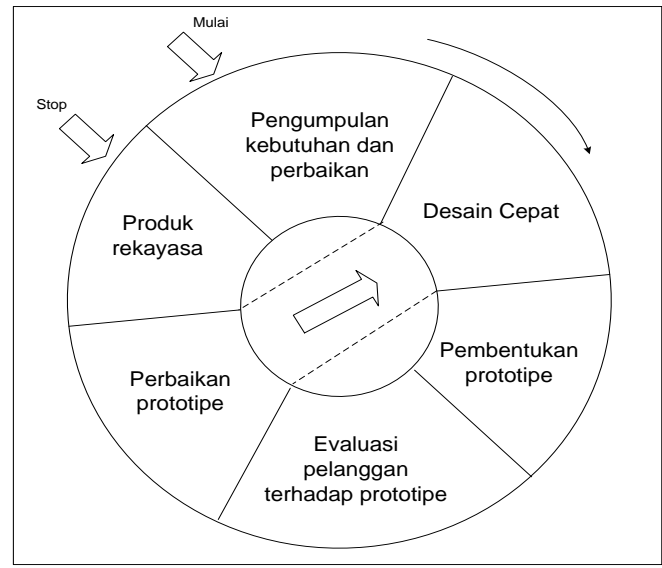

Gambar 1. Diagram Pengembangan Perangkat Lunak

Pertama proses analisis desain pengolahan koleksi karya ilmiah mahasiswadilakukan,kemudian

dilanjutkan pada tahap penyusunan rancang bangun sistem otomasi pengolahan koleksi karya ilmiah mahasiswa. Rancang bangun yang dikembangkan mencakup: (a) diagram use-case; (b) Rancangan database dengan ERD (Entity Relationship Diagram); (c) Diagram aktivitas Rancang bangun yang tersusun kemudian diimplementasikan menjadi perangkat lunak sistem otomasi pengolahan koleksi karya ilmiah mahasiswa. Komponen-komponen sistem otomasi pengolahan koleksi karya ilmiah mahasiswa diimplementasikan mencakup: (a) antarmuka program (interface); (b) koneksi (link), dan (a) fitur-fitur layanan.

Komponen-komponen tersebut kemudian diintegrasikan menjadi produk akhir perangkat lunak sistem otomasi pengolahan koleksi karya ilmiah mahasiswa. Perangkat lunak sistem otomasi pengolahan koleksi karya ilmiah mahasiswa yang sudah jadi kemudian dievaluasi. Evaluasi dilakukan oleh pakar dan pengguna. Pembuatan sistem otomasi pengolahan koleksi karya ilmiah mahasiswa melibatkan dua bidang keahlian yaitu keahlian di bidang perpustakaan (pustakawan) dan keahlian di bidang teknologi informasi. Dengan demikian pakar yang dilibatkan dalam evaluasi adalah pakar teknologi informasi dan pustakawan. Berdasarkan evaluasi oleh pakar dan pengguna, dilakukan revisi terhadap sistem otomasi pengolahan koleksi karya ilmiah mahasiswa. Evaluasi dan revisi dilakukan berulang-ulang sampai sistem otomasi pengolahan koleksi karya ilmiah mahasiswa memenuhi kreteria atau kebutuhan pengguna dan sudah dinyatakan layak untuk diproduksi. Revisi dapatdilakukan mulai dari rancang bangun dan seterusnya hingga implementasi atau revisi pada 
implementasi saja, tergantung kesalahan yang terjadi, apabila kesalahan hanya terjadi pada sintaks pemrograman maka revisi hanya dilakukan pada implementasi. Apabila kesalahan terjadi pada desain maka perbaikan dilakukan mulai rancang bangun dan dilanjutkan dengan revisi pada implementasi.

\section{Metode Ujicoba}

Perangkat lunak sistem otomasi pengolahan koleksi karya ilmiah yang sudah dikembangkan kemudian diintegrasikan dengan program bebas pustaka online yang ada di web UNDIKSHA dengan alamat $h t t p: w w w$. Undiksha.ac.id. Selanjutnya, perangkat lunak tersebut diujicoba oleh pakar dan pengguna sistem. Pakar melakukan penilaian perangkat lunak dengan mengobservasi bagian internal program dan mencoba menjalankannya. Beberapa indikator penilaian terhadap perangkat lunak yang dihasilkan menurut Candiasa (2012:66) adalah kebenaran atau ketepatan operasional sistem, kemampuan program untuk mengantisipasi kondisi abnormal dalam menjalankan fungsinya, kemudahan untuk mengadaptasikan program bila terjadi perubahan spesifikasi, keberadaan program untuk bisa dipergunakan kembali baik sebagian atau seluruhnya untuk aplikasi lain, efisiensi terhadap sumber daya, kemudahan program ditransfer ke perangkat keras yang berbeda, kemudahan untuk menelusuri kegagalan program dan validasi, kemampuan program memproteksi diri dari penggunaan dan modifikasi illegal, kejelasan pengaturanmodul-modul dalam program, dan keterbacaan program oleh orang lain selain programmer.

Setelah mengobservasi bagian internal sistem otomasi pengolahan koleksi karya ilmiah mahasiswa dan mengobservasi hasil eksekusi program, pakar melakukan penilaian menggunakan instrumen di atas. Pada kolom kualifikasi penilai menuliskan kualifikasi sangat baik, baik, cukup memadai, kurang atau sangat kurang sesuai penilaian pakar. Pakar juga diminta untuk menuliskan komentar secara umum kinerja perangkat lunak pada kolom yang disediakan.

Rekomendasi dari pakar dari hasil ujicoba ditindaklanjuti dengan proses perbaikan perangkat lunak. Setelah dilakukan perbaikan perangkat lunak, selanjutnya dilakukan ujicoba terhadap beberapa pustakawan dan mahasiswa Undiksha. Indikator-indikator penilaian yang digunakan antara lain kinerja perangkat lunak, kemudahan pemakaian dan pengoperasian perangkat lunak, keramahan perangkat lunak untuk memberi petunjuk pada pengguna, dan kebermanfaatan perangkat lunak bagi pengguna. Penilaian dilakukan dengan menuliskan kualifikasi sangat baik, baik, cukup memadai, kurang atau sangat kurang disertai komentar secukupnya sesuai penilaian masing-masing pustakawan dan mahasiswa yang menjadi sampel uji coba. Pustakawan yang menjadi sampel uji coba memberikan petunjuk pada mahasiswa yang ditunjuk sebagai sampel. Indikator-indikator penilaian yang digunakan untuk penilaian oleh mahasiswa sama dengan indikator penilaian pustakawan yakni kinerja perangkat lunak, kemudahan pemakaian dan pengoperasian 
perangkat lunak, keramahan perangkat lunak untuk memberi petunjuk pada pengguna, dan kebermanfaatan perangkat lunak bagi pengguna. Hanya saja indikator-indikator tersebut dilihat dari sudut pandang mahasiswa sebagai pengguna sistem otomasi penelusuran informasi koleksi karya ilmiah melalui modul OPAC.

\section{HASIL DAN PEMBAHASAN \\ Hasil Rancang Bangun Program Sistem Otomasi pengolahan Koleksi IImiah Mahasiswa}

Pengembangan sistem otomasi pengolahan karya ilmiah mahasiswa berbasis web ini memilki 2 (dua) rancangan program yaitu program pengolahan koleksi dan program OPAC (online public access catalogue). Program pengolahan koleksi dirancang untuk pegawai perpustakaan (pustakawan) yang bertugas untuk pengolahan koleksi karya ilmiah mahasiswa sedangkan program OPAC dirancang untuk pengguna (mahasiswa) yang ingin melakukan penelusuran informasi koleksi karya ilmiah mahasiswa. Rancangan database dapat dilihat pada gambar 2 di bawah ini.

Rancangan Database Menggunakan ERD(Entity Relationship Diagram)

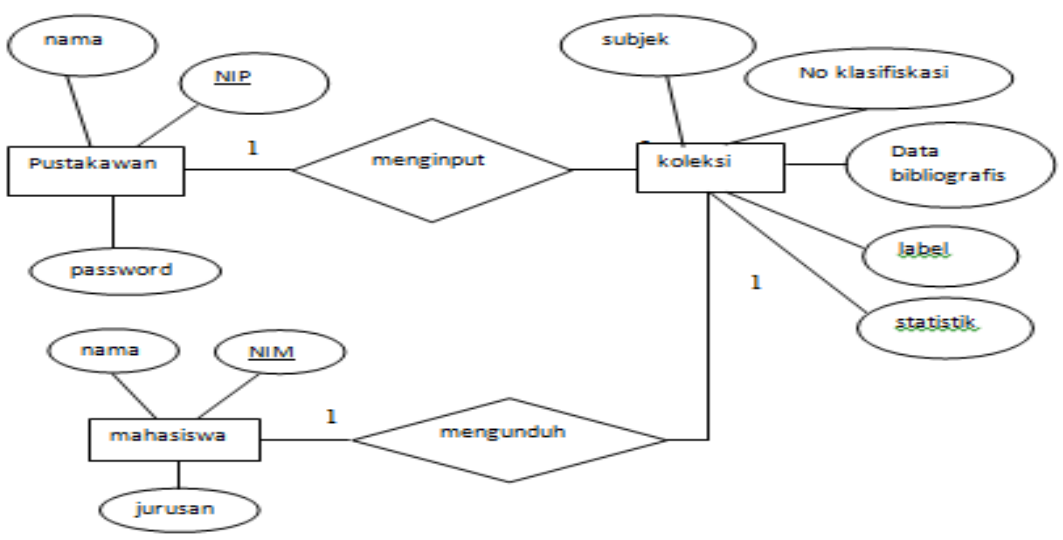

Gambar 2. Rancangan database dengan menggunakan ERD 
Data Flow Diagram (DFD) Program Sistem Otomasi Pengolahan Koleksi Karya IImiah Mahasiswa Berbasis Web dapat dilihat ada gambar 3.

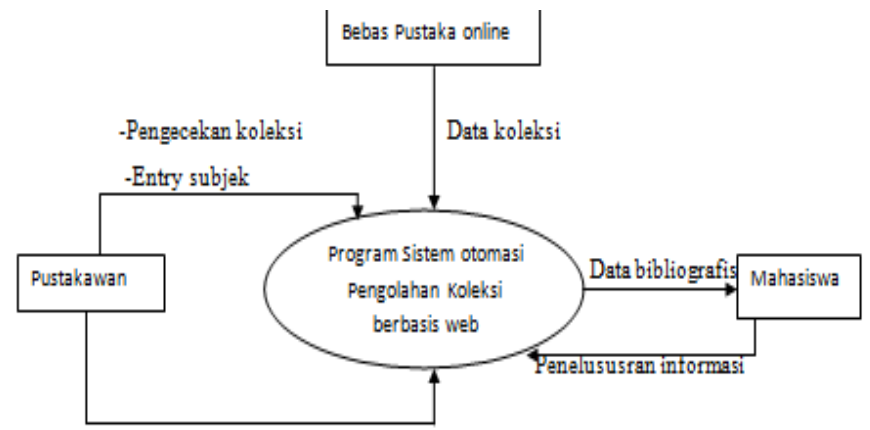

Pengolahan koleksi (kode klasifikasi, Label, katalog, statistik)

Gambar 3. Data Flow Diagram Program Sistem Otomasi Pengolahan Koleksi Karya IImiah Mahasiswa Berbasis Web

\section{Implementasi Perangkat Lunak}

Rancang bangun sistem otomasi pengolahan koleksi karya ilmiah mahasiswa berbasis web diimplementasikan menjadi perangkat lunak dengan menggunakan PHP sebagai bahasa pemrograman, MySql sebagai basis data pendukung, Linux Ubuntu 10.04 server sebagai sistem operasi dan Apache sebagai web server.

Berikut ini tampilan beberapa modul dari program pengolahan koleksi karya ilmiah :

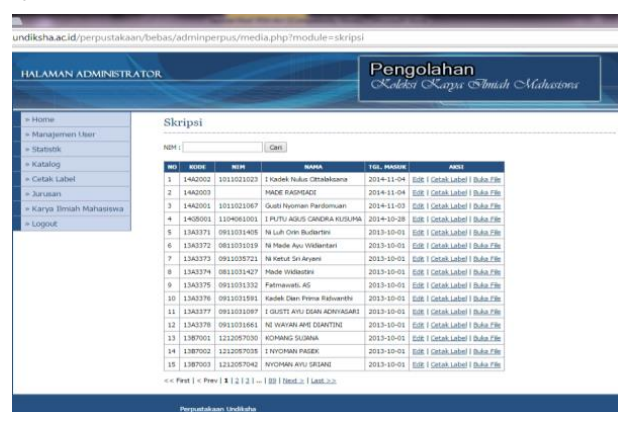

Gambar 4. tampilan password
Sebelum membuka program pengolahan koleksi karya ilmiah, administrator harus memasukkan nama user dan password terlebih dahulu. Dapat dilihat pada gambar.

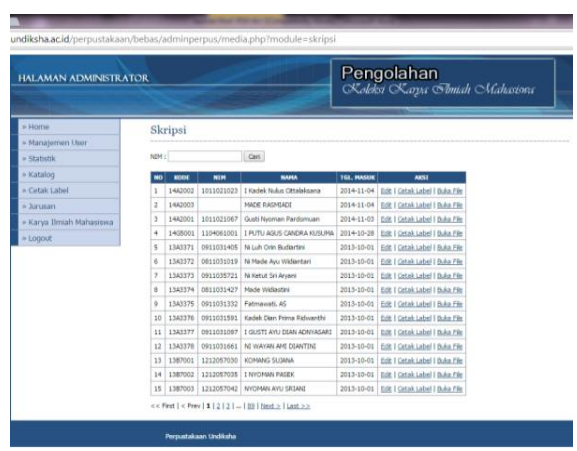

Gambar 5. tampilan depan program

Tampilan depan program ini menampilkan kode skripsi, NIM (no induk mahasiswa) tanggal masuk data,edit, dan buka file. Seperti pada tampilan pada gambar 6 . 


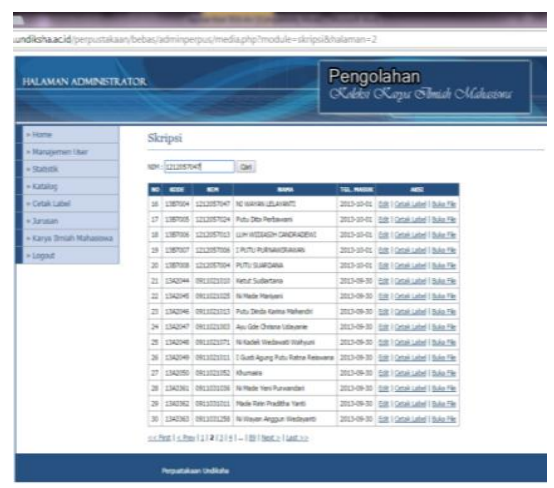

Gambar 6. tampilan pencarian skripsi berdasarkan NIM

Pada modul ini digunakan untuk pengecekan skripsi yang masuk ke program pengolahan koleksi atau pencarian skripsi dengan kodenya atau no klasifikasinya yang diinginkan untuk pengolahan koleksi terutama pada pelabelan. Seperti tampilan pada gambar 7 .

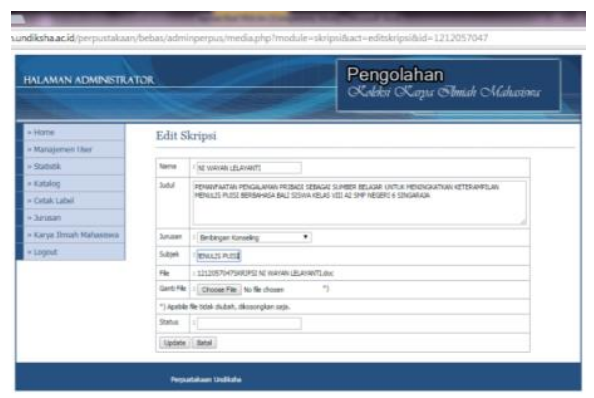

Gambar 7. Tampilan edit skripsi atau entry subjek

Pada tampilan ini digunakan untuk memasukkan subjek sesuai dengan tema dari skripsi atau tugas akhirnya. Hal ini diperlukan untuk data bibliografis koleksi dan bukti fisik sebagai angka kredit yang dibutuhkan oleh pustakawan untuk kenaikan jabatan. Seperti tampilan pada gambar 8 .

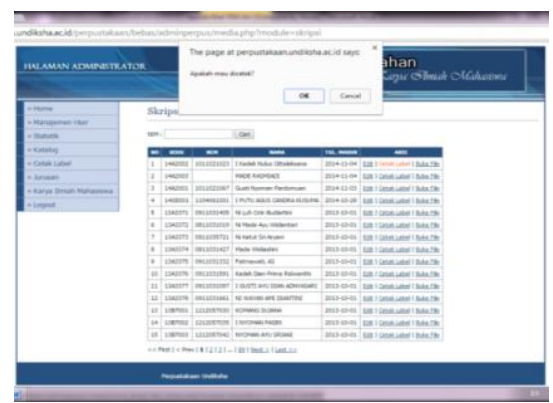

Gambar 8. Tampilan cetak label

Dalam pencetakkan label ini, terlebih dahulu dipilih koleksi yang akan dicetak dengan mengklik cetak label pada fitur aksi, kemudian akan ditampilkan pertanyaan yang muncul diatas tampilan dan seterusnya klik ok.

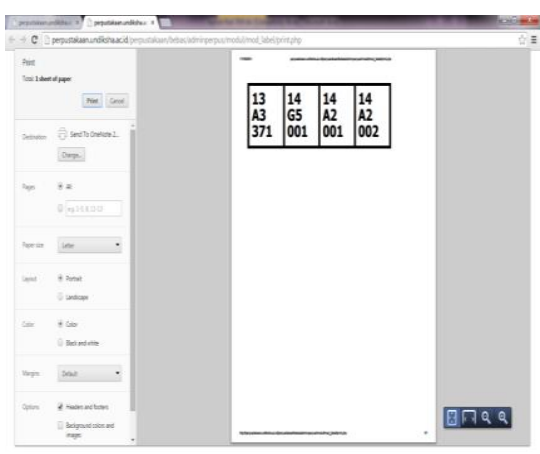

Gambar 9. tampilan no label

Label siap untuk dicetak dengan fasilitas pengaturan print yang telah tersedia seperti yang terlihat pada gambar 10 .

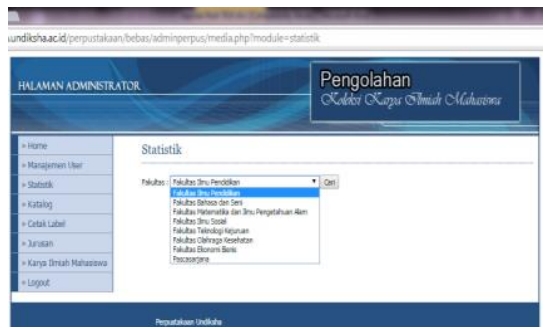

Gambar 10. Tampilan Statistik

Jurnal Sains dan Teknologi |544 
Pada modul ini disajikan statistik berdasarkan fakultas dengan memilih fakultas pada kolom yang tersedia. Seperti yang terlihat pada gambar $11 \mathrm{di}$ bawah ini.

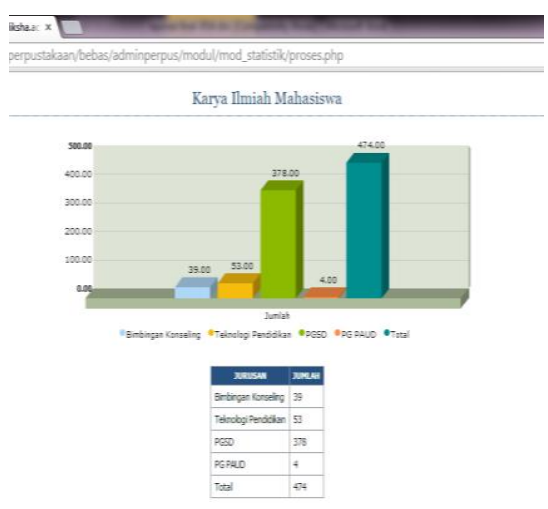

Gambar 11. Tampilan grafik statistik

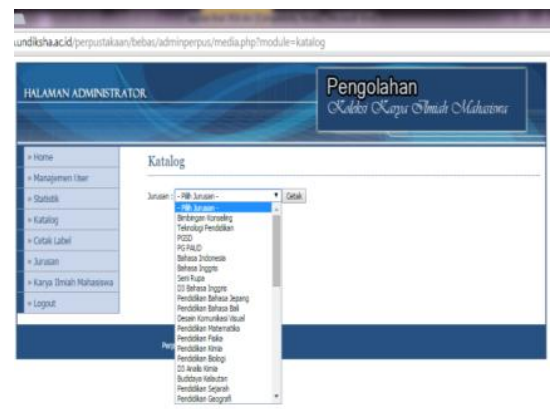

Gambar 12. Tampilan katalog

Modul katalog digunakan untuk pembuatan data bibliografis koleksi sebagai alat penelusuran informasi koleksi atau katalog manual. Pilih jurusan yang akan dicetak katalognya kemudian klik cetak, maka akan ditampilkan data bibliografis koleksi berdasarkan jurusan seperti gambar 13 dibawah ini.

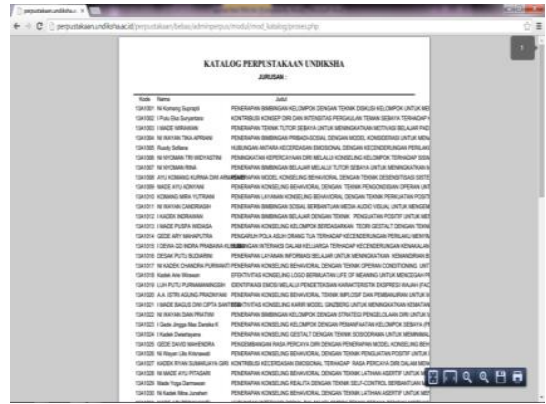

Gambar 13. Tampilan data bibliografis

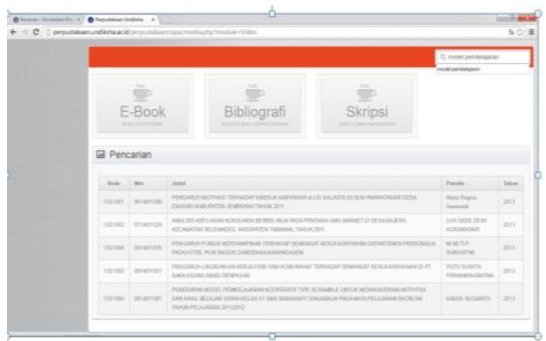

Gambar 14. Tampilan skripsi

Pada modul ini ditampilkan data bibliografis koleksi karya ilmiah mahasiswa seperti kode koleksi, NIM, judul, penulis dan tahun terbit. Pencarian dilakukan dengan mengetik judul/subjek/kata kunci/penulis.

\section{Hasil Ujicoba Terbatas}

Program sistem otomasi pengolahan koleksi karya ilmiah mahasiswa berbasis web telah diuji melalui beberapa pola pengujian. Uji kelayakan oleh pakar teknologi informasi, uji keterpakaian oleh petugas perpustakaan (pustakawan) dan mahasiswa. Hasil ujicoba adalah sebagai berikut : 
Tabel 1. Hasil Penilaian oleh Pakar Teknologi Informasi

\begin{tabular}{|c|c|c|c|}
\hline No & Indikator & Deskriptor & Kualifikasi \\
\hline 1. & $\begin{array}{l}\text { Kebenaran } \\
\text { (Correctness) }\end{array}$ & $\begin{array}{lcr}\text { Kemampuan } & \text { program } & \text { dalam } \\
\text { mengerjakan } & \text { tugasnya } & \text { sesuai } \\
\text { dengan permintaan dan spesifikasi }\end{array}$ & $\begin{array}{l}\text { Baik, sudah sesuai dengan } \\
\text { spesifikasinya }\end{array}$ \\
\hline 2. & $\begin{array}{l}\text { Ketegaran } \\
\text { (Robustness) }\end{array}$ & $\begin{array}{l}\text { Kemampuan program untuk } \\
\text { mengantisipasi kondisi abnormal } \\
\text { dalam menjalankan fungsinya }\end{array}$ & $\begin{array}{l}\text { Cukup Memadai, program } \\
\text { sudah diantisipasi agar mampu } \\
\text { menjalankan fungsinya pada } \\
\text { kondisi abnormal. }\end{array}$ \\
\hline 3. & $\begin{array}{l}\text { Keterluasan } \\
\text { (Extendibility) }\end{array}$ & $\begin{array}{l}\text { kemudahan untuk } \\
\text { mengadaptasikan program bila } \\
\text { terjadi perubahan spesifikasi }\end{array}$ & $\begin{array}{l}\text { Baik, dengan mudah dilakukan } \\
\text { perubahan spesifikasi pada } \\
\text { program ini. }\end{array}$ \\
\hline 4. & $\begin{array}{l}\text { Keterpakaian } \\
\text { ulang } \\
\text { (Reusability) }\end{array}$ & 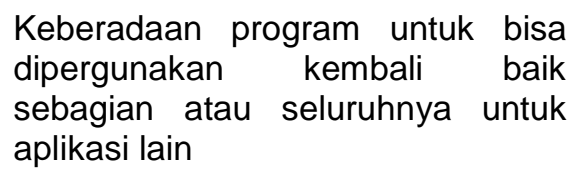 & $\begin{array}{l}\text { Cukup memadai, dapat } \\
\text { dipergunakan untuk aplikasi } \\
\text { lain tapi harus sesuai dengan } \\
\text { formatnya. }\end{array}$ \\
\hline 5. & $\begin{array}{l}\text { Efisiensi atau } \\
\text { Kinerja }\end{array}$ & Efisiensi terhadap sumber daya & $\begin{array}{l}\text { Baik,mampu menggunakan } \\
\text { sumber dengan baik. }\end{array}$ \\
\hline 6. & $\begin{array}{l}\text { Portabilitas } \\
\text { (Portability) }\end{array}$ & $\begin{array}{l}\text { Kemudahan program ditransfer ke } \\
\text { perangkat keras yang berbeda }\end{array}$ & $\begin{array}{l}\text { Baik, dapat dengan mudah } \\
\text { ditransfer ke hardware yang } \\
\text { berbeda. }\end{array}$ \\
\hline 7. & Verifikasi & $\begin{array}{l}\text { Kemudahan untuk menelusuri } \\
\text { kegagalan program dan validasi }\end{array}$ & $\begin{array}{l}\text { Baik, program ini mudah } \\
\text { dilakukan perbaikan. }\end{array}$ \\
\hline 8. & $\begin{array}{l}\text { Integritas } \\
\text { (Integrity) }\end{array}$ & $\begin{array}{l}\text { Kemampuan program memproteksi } \\
\text { diri dari penggunaan dan modifikasi } \\
\text { illegal }\end{array}$ & $\begin{array}{l}\text { Cukup memadai, program ini } \\
\text { sudah diproteksi dari } \\
\text { penggunaan illegal. }\end{array}$ \\
\hline 9. & $\begin{array}{l}\text { Modularitas } \\
\text { (Modularity) }\end{array}$ & $\begin{array}{l}\text { Pengaturan program dalam modul- } \\
\text { modul }\end{array}$ & $\begin{array}{l}\text { Baik, pengaturan program } \\
\text { dalam modul-modul sudah } \\
\text { sesuai dengan fungsinya. }\end{array}$ \\
\hline 10. & $\begin{array}{l}\text { Keterbacaan } \\
\text { (Readability) }\end{array}$ & $\begin{array}{l}\text { Keterbacaan program oleh orang } \\
\text { lain selain programmer }\end{array}$ & $\begin{array}{l}\text { Baik, program ini bisa dipahami } \\
\text { oleh orang lain selain } \\
\text { programmer. }\end{array}$ \\
\hline
\end{tabular}

Berdasarkan penilaian oleh pakar teknologi informasi bahwa indikator penilaian meliputi kebenaran, keterluasan, efesiensi, portabilitas, verifikasi, modularitas dan keterbacaan mendapatkan kualifikasi baik, sedangkan ketegaran, keterpakaian ulang dan integritas mendapatkan kualifikasi cukup memadai yang perluditingkatkan lagi. Secara umum dari hasil penilaian tersebut dapat dikatakan program tersebut sudah baik artinya sudah cukup layak untuk digunakan oleh pengguna sebagai pengolahan dan penelusuran informasi koleksi karya ilmiah mahasiswa yang berbasis web. 
Tabel 2. Hasil Penilaian oleh Pengguna (Pustakawan dan Mahasiswa)

\begin{tabular}{|c|c|c|c|}
\hline No & Indikator & Deskriptor & Kualifikasi \\
\hline 1. & Kinerja & $\begin{array}{lcc}\text { Efektifitas } & \text { layanan } & \text { yang } \\
\text { diberikan } & \text { perangkat } & \text { lunak } \\
\text { sesuai dengan permintaan dan }\end{array}$ & $\begin{array}{l}\text { Baik, program ini sudah sesuai } \\
\text { dengan permintaan dan } \\
\text { spesifikasi. }\end{array}$ \\
\hline 2. & $\begin{array}{l}\text { Kemudahan } \\
\text { pemakaian }\end{array}$ & $\begin{array}{l}\text { Tingkat kemudahan pemakaian } \\
\text { pengoperasian perangkat } \\
\text { lunak }\end{array}$ & $\begin{array}{l}\text { Baik, mudah dioperasikan serta } \\
\text { kemudahan dalam pemasukan } \\
\text { data dan interpretasi hasil. }\end{array}$ \\
\hline 3. & Keramahan & $\begin{array}{l}\text { keramahan perangkat lunak } \\
\text { untuk memberi petunjuk pada } \\
\text { pengguna }\end{array}$ & $\begin{array}{l}\text { Sudah baik, ikon-ikon yang } \\
\text { sudah jelas. }\end{array}$ \\
\hline 4. & Kebergunaan & $\begin{array}{l}\text { Kebermanfaatan atau } \\
\text { kebergunaan perangkat lunak } \\
\text { bagi pengguna }\end{array}$ & $\begin{array}{l}\text { Sangat baik, program ini dapat } \\
\text { memudahkan pengolahan dan } \\
\text { penelusuran informasi koleksi. }\end{array}$ \\
\hline
\end{tabular}

Berdasarkan hasil penilaian oleh pengguna didapatkan bahwa kinerja, kemudahan pemakaian, keramahan, dan kebergunaanperangkat lunak ini memiliki kualifikasi baik berarti program ini sudah layak untuk digunakan oleh pemakai.

\section{PEMBAHASAN}

Sistem otomasi pengolahan koleksi karya ilmiah mahasiswa berbasis web telah diimplementasikan. Pengembangan perangkat lunak ini dibagi menjadi dua program yaitu pengolahan koleksi danpenelusuran informasi atau OPAC. Fitur yang disajikan pada modul pengolahan koleksi adalah pembuatan kode klasifikasi, pencetakan label, pembuatan katalog, pembuatan statistik dan subjek. Program OPAC menyediakan penelusuran informasi online tentang koleksi karya ilmiah mahasiswa Undiksha dengan mengakses judul atau penulisnya. Dengan pengembangan program ini dapat dilakukan pengolahan koleksi karya ilmiah mahasiswa secara otomatis seperti pembuatan kode klasifikasi, pencetakan label, pembuatan katalog dan pembuatan statistik. Sedangkan untuk memasukan subjek bahan pustaka atau koleksi masih dilakukan manual oleh petugas perpustakaan (pustakawan) karena menentukan subjek diperlukan kemampuan untuk analisa isi (content) dari bahan pustaka tersebut berdasarkan kepustakawanan atau ilmu perpustakaan yang disebut analisis subjek. Dengan pengembangan program ini, pengolahan koleksi yang dilakukan oleh petugas perpustakaan dapat dilakukan dengan mudah, cepat dan akurat, sehingga koleksi dapat dilayankan ke pengguna dengan cepat dan dapat dimanfaatkan secara optimal.

Pada pengembangan sistem otomasi pengolahan koleksi karya ilmiah mahasiswa berbasis web terdapat penelusuran informasi atau OPAC bertujuan untuk mengetahui koleksi yang tersedia dan dapat mengetahui kode klasifikasi yang digunakan sebagai acuan untuk pencarian koleksi di rak 
penyimpanan, sehingga koleksi dapat ditemukan dengan cepat, mudah dan benar. Penelusuran informasi ini dapat diakses di internet agar dapat ditelusuri kapan saja dan dimana saja asalkan terhubung internet.

Sistem otomasi pengolahan koleksi karya ilmiah mahasiswa berbasis web yang dikembangkan sudah diuji oleh pakar teknologi informasi. Hasilnya menunjukkan bahwa pengolahan koleksi karya ilmiah mahasiswa berbasis web sudah memenuhi unsur kebenaran fungsi program sesuai spesifikasi yang ditentukan yaitu sebagai pengolahan koleksi karya ilmiah mahasiswa secara otomatis yang dapat diakses di internet sehingga petugas perpustakaan dapat melakukan tugasnya bukan saja di tempat kerja tapi dapat dilakukan dimana dan kapan saja yang terpenting terhubung internet. Begitu pula penelusuran informasi koleksi yang bisa diakses di internet. Ketegaran sistem untuk mengantisipasi kondisi abnormal juga sudah dipandang cukup memadai sepanjang tidak terkait koneksifitas. Kemudahan perangkat lunak untuk beradaptasi bila terjadi perubahan spesifikasi dinilai sudah baik. Demikian pula keterpakaian sebagian atau seluruh sistem untuk aplikasi lain sudah cukup memadai. Kemampuan program untuk menggunakan sumber daya, sudah baik. Kemudahan program untuk ditransfer ke lingkungan perangkat keras yang berbeda sudah dinilai baik. Verifikasi untuk menelusuri kegagalan program baik masih dalam validasi maupun setelah operasi mudah dilakukan. Kemampuan perangkat lunak untuk memproteksi diri dari penggunaan dan modifikasi illegal sudah cukup memadai tapi masih perlu ditingkatkan.
Kejelasan pengaturan modul-modul dalam perangkat lunak dinilai sudah baik. Begitu pula dengan keterbacaan perangkat lunak oleh orang lain selain programmer juga sudah cukup memadai. Beberapa masukan yang diberikan oleh pakar antara lain : 1) Keterpakaian ulang (Reusability) program agar bisa dipergunakan kembali sebagian atau seluruhnya untuk aplikasi lain, perlu ditingkatkan lagi dengan baik dengan mengikuti format yang umum sehingga dapat dengan mudah dilakukan. 2) tampilan pada modul katalog perlu diperbaiki untuk mendapatkan hasil yang memuaskan. 3) perlu menyedikan server dengan kapasitas yang memadai agar dapat menampung data yang banyak karena program ini terintegrasi dengan bebas pustaka online.

Perangkat lunak ini juga sudah diujicoba secara imperik dengan melibatkan lima orang pegawai perpustakaan dan lima mahasiswa. Hasil ujicoba menunjukkan bahwa kinerja program untuk melakukan pengolahan koleksi karya ilmiah dan penelusuran informasinya sudah baik. Program ini mudah dioperasikan sehingga tidak diperlukan keahlian khusus untuk mengoperasikannya. Petunjuk pemakaian pada program ini sudah cukup jelas dan respon kepada pengguna sudah cukup lengkap. Perangkat lunak ini dinilai sangat berguna dalam pengolahan dan penelusuran informasi koleksi karya ilmiah mahasiswa dengan mudah, cepat dan akurat. Beberapa masukkan yang disampaikan oleh pustakawan dan mahasiswa antara lain: 1) persediaan perangkat keras yang memadai perlu diperhatikan sebagai pendukung 
kelancaran pengembangan sistem otomasi ini. 2) pada penelusuran informasi atau OPAC perlu ditambahkan modul abstraknya agar ada gambaran tentang content koleksi. 3) jaringan internet yang disediakan lembaga undiksha agar dioptimalkan karena sering terjadi akses yang lambat.

Berdasarkan hasil dari beberapa pengujian yakni uji kelayakan oleh pakar teknologi informasi dan uji keterpakaian oleh petugas perpustakaan dan mahasiswa sebagai pengguna, maka dapat diuraikan hasil ujicoba sebagai berikut: (1) Pengembangan sistem otomasi pengolahan koleksi karya ilmiah mahasiswa berbasis web sudah sesuai dengan spesifikasi yang telah ditentukan sebagai pengolahan dan penelusuran informasi koleksi karya ilmiah mahasiswa yang dilakukan secara otomatis oleh program dengan mudah, cepat dan akurat. (2) Pengolahan dan penelusuran informasi koleksi karya ilmiah mahasiswa bisa diakses di internet sehingga petugas perpustakaan dapat melakukan pekerjaannya dimana dan kapan saja asalkan terhubung internet. Begitu pula dengan pengguna seperti mahasiswa dapat melakukan penelusuran informasi koleksi dengan mudah dimana dan kapan saja. (3) Perangkat lunak ini dapat dioperasikan dengan mudah, tidak terlalu teknis, sehingga tidak perlu dilakukan pelatihan yang khusus kepada pengguna. (4) Indikator penilaian dari program ini seperti: kebenaran, keterluasan,efesiensi, portabilitas, verifikasi, modularitas dan keterbacaan kinerja, kemudahan pemakaian, keramahan, dan kebergunaan mendapatkan kualifikasi baik, sedangkan ketegaran, keterpakaian ulang dan integritas yang dinilai oleh pakar teknologi informasi dengan kualifikasi cukup memadai yang perlu ditingkatkan lagi. Secara umum dari hasil penilaian tersebut dapat dikatakan program tersebut sudah baik artinya sudah cukup layak untuk digunakan oleh pengguna sebagai pengolahan dan penelusuran informasi koleksi karya ilmiah mahasiswa yang berbasis web. (5) Secara umum, perangkat lunak ini sudah cukup layak untuk digunakan tapi ada beberapa hal yang perlu ditingkatkan seperti pada modul penelusuran informasi perlu ditambahkan abstrak agar pengguna memperoleh gambaran dari isi koleksi yang inginkan, proteksi program dari pengguna dan modifikasi illegal perlu ditingkatkan. Keterpakaian ulang (Reusability)program agar bisa dipergunakan kembali sebagian atau seluruhnya untuk aplikasi lainperlu ditingkatkan lagi dengan baik dengan mengikuti format yang umum sehingga dapat dengan mudah dilakukan. Tampilan pada modul katalog perlu diperbaiki untuk mendapatkan hasil yang memuaskan. Diperlukan penyediaan server dengan kapasitas yang memadai agar dapat menampung data yang banyak karena program ini terintegrasi dengan bebas pustaka online. 


\section{SIMPULAN}

$\begin{array}{crr}\text { Pengembangan } & \text { sistem } & \text { otomasi } \\ \text { pengolahan koleksi } & \text { karya } & \text { ilmiah } \\ \text { mahasiswa berbasis } & \text { web } & \text { sudah }\end{array}$ diimplementasikan dan diintegrasikan dengan program bebas pustaka online yang sudah dihasilkan pada penelitian sebelumnya. Pengembangan sistem otomasi ini dibagi menjadi dua program utama yaitu pengolahan koleksi dan penelusuran informasi atau OPAC. Fitur yang disajikan pada program pengolahan koleksi adalah pembuatan kode klasifikasi, pencetakan label, pembuatan katalog, pembuatan statistik dan subjek. Program OPAC menyediakan penelusuran informasi online tentang koleksi karya ilmiah mahasiswa Undiksha dengan mengakses judul/katakunci/penulisnya. Dengan pengembangan program tersebut dapat dilakukan pengolahan koleksi karya ilmiah mahasiswa secara otomatis seperti pembuatan kode klasifikasi, pencetakan label, pembuatan katalog dan pembuatan statistik. Pengolahan dan penelusuran informasi koleksi karya ilmiah mahasiswa bisa diakses di internet sehingga petugas perpustakaan dapat melakukan pekerjaannya dimana dan kapan saja asalkan terhubung internet. Begitu pula dengan pengguna seperti mahasiswa dapat melakukan penelusuran informasi koleksi dengan mudah dimana dan kapan saja.

Berdasarkan hasil dari beberapa pengujian yakni uji kelayakan oleh pakar teknologi informasi dan uji keterpakaian oleh petugas perpustakaan dan mahasiswa sebagai pengguna, maka dapat diuraikan hasil ujicoba sebagai berikut : 1) Pengembangan sistem otomasi pengolahan koleksi karya ilmiah mahasiswa berbasis web sudah sesuai dengan spesifikasi yang telah ditentukan sebagai pengolahan dan penelusuran informasi koleksi karya ilmiah mahasiswa yang dilakukan secara otomatis oleh program dengan mudah, cepat dan akurat. 2) Perangkat lunak ini dapat dioperasikan dengan mudah, tidak terlalu teknis, sehingga tidak perlu dilakukan pelatihan yang khusus kepada pengguna. 3) Indikator penilaian dari program ini seperti: kebenaran, keterluasan,efesiensi, portabilitas, verifikasi, modularitas, keterbacaan kinerja, kemudahan pemakaian, keramahan, dan kebergunaan mendapatkan kualifikasi baik, sedangkan ketegaran, keterpakaian ulang dan integritas mendapatkan kualifikasi cukup memadai yang perlu ditingkatkan lagi. 3) Secara umum dari hasil penilaian tersebut dapat dikatakan program tersebut sudah baik artinya sudah cukup layak untuk digunakan oleh pengguna sebagai pengolahan dan penelusuran informasi koleksi karya ilmiah mahasiswa yang berbasis web.

Sistem otomasi pengolahan koleksi karya ilmiah mahasiswa berbasis web ini sudah dikembangkan dan sudah diujicoba secara terbatas. Hasilnyamenunjukkan

kebermanfaatannya untuk membantu petugas perpustakaan (pustakawan) dalam melakukan pekerjaan pengolahan koleksi karya ilmiah mahasiswa dengan mudah, cepat dan akurat karena pekerjaan tersebut sudah secara otomatis dilakukan oleh program tersebut. Begitu pula bagi pengguna perpustakaan terutama mahasiswa dapat menggunakan program penelusuran informasi koleksi karya ilmiah mahasiswa berbasis web, yang 
bisa diakses di internet, sehingga bisa dilakukan dimana dan kapan saja. Oleh karena itu kepada para pengguna perpustakaan Undiksha disarankan untuk memanfaatkan portal web tersebut untuk memudahkan melakukan penelusuran informasi tentang koleksi karya ilmiah mahasiswa Undiksha.

Program ini masih terbuka untuk dikembangkan baik secara teknis maupun ide. Terutama bagi pengelola perpustakaan Undiksha disarankan untuk mengembangkan program ini demi upaya peningkatan kualitas layanan perpustakaan dan pengelolaan perpustakaan secara professional sesuai perkembangan teknologi informasi.

\section{UCAPAN TERIMAKASIH}

Penghargaan dan terima kasih diberikan kepada Direktur Pembinaan Penelitian dan Pengabdian Kepada Masyarakat (Ditbinlitabmas) Direktorat Jenderal Pendidikan Tinggi Depdiknas yang telah memberikan bantuan dana sehingga penelitian ini dapat berjalan sesuai rencana dan keinginan peneliti. Penelitian ini dibiayai dari dana DIPA Universitas Pendidikan Ganesha dengan SPK Nomor: 99 /UN48.14/PL/2014 Tanggal 6 Maret 2014

\section{DAFTAR PUSTAKA}

Candiasa, I Made,dkk. 2012. Pemerataan dan Peningkatan Mutu Pendidikan Melalui Komunitas Guru Online. Laporan Penelitian DIPA. Lembaga Penelitian Undiksha
Corbin, J.1985. Managing The Library Automation Project. Canada:Oryx Press.

Lutriani. 2011. Digital Library : Penerapan Teknologi Informasi (TI) Di Perpustakaan. Media Pustakawan. Vol. 18 No. 3 \& 4(38)

Pramita Utami, Ni Putu. 2011.Pengembangan Program Notifikasi Berbasis Komputer Untuk Memperlancar Proses Pengembalian Buku Pinjaman Pada Perpustakaan Universitas Pendidikan Ganesha. Laporan Penelitian DIPA. Lembaga Penelitian Undiksha

Prastowo, Andi. 2012. Manajemen Perpustakaan Sekolah Profesional. Jogjakarta:DIVA Press

Rahayu, Sri. 2011. Optimalisasi Fitur Pengindeksan Winisis Untuk Ketepatan dan Kecepatan Layanan Penelusuran Pustaka Kelabu. Jurnal Pustakawan Indonesia . Vol. 11 No.2(14)

Retno Wulan, Ni Gusti Ayu Ketut,dkk. 2009. Optimalisasi Sistem Otomasi Sebagai Upaya Peningkatan Layanan Penelusuran Koleksi Buku Bagi Pengguna Di Perpustakaan Universitas Pendidikan Ganesha. Laporan Penelitian DIPA. Lembaga Penelitian Undiksha

Retno Wulan, Ni Gusti Ayu Ketut,dkk. 2011. Pengembangan Layanan Penelusuran Koleksi Skripsi dan Tugas Akhir Dengan E-Book Berbasis Sistem Electronic Resources di Perpustakaan Universitas Pendidikan Ganesha. Laporan Penelitian DIPA. Lembaga Penelitian Undiksha

Jurnal Sains dan Teknologi |551 
Rowley, JE. 1980.Computers Libraries. London:Clive Bingley

Setemen, K, dkk. 2012. Pengembangan Aplikasi Pengelolaan Karya IlmiahMahasiswa dan Dosen Berbasis Teknologi Web. Jurnal Sains\&Teknologi. Vol. 1 No.2 (107)

Soeatminah. 1992. Perpustakaan Kepustakawanan dan Pustakawan. Yogyakarta:Penerbit Kanisius.

Sugiarti, Yuni .2011. Peranan Teknologi Internet dalam Membangun
Pendidikan Karakter Anak. Jurnal Teknodik. Vol. XXV No.2(145)

Sugiyono. 2009. Metode Penelitian Kuantitatif, Kualitatif dan R\&D. Bandung:Alfabeta

Suminarsih, Eka Meifrina. 2010. Pengembangan Perpustakaan Digital Untuk Meningkatkan Pemanfaatan Grey Literature Di Indonesia

Supriyanto, Wahyu. 2008. Teknologi Informasi Perpustakaan. Yogyakarta:Kanisius

UU RI 43 Tahun 2007.Jakarta: Perpustakaan Nasional RI. 